\title{
Gender Differences in Political Participation in Britain: Traditional, Radical and Revisionist Models*
}

IN RECENT YEARS QUESTIONS ABOUT THE EXTENT AND nature of gender differences in political participation have proved controversial. Within the literature we can identify three main perspectives. The traditional view, common in the $1950 \mathrm{~s}$ and $1960 \mathrm{~s}$, was that women tended to be less involved and interested in most conventional forms of political life, whether in terms of elected office, party membership, interest group activity, or campaign work, and, to a lesser extent, in voting. The paucity of women in parliamentary elites therefore seemed consistent with their general lack of interest in political life. Debates about the causes of the participation gap tended to revolve around the relative importance of gender differences in structural life-styles (domestic constraints, socio-economic resources, and organizational affiliations) and/or political attitudes (sex role socialization, political efficacy and confidence). The traditional perspective may have become less popular but it continues to receive support from some recent studies.

Yet during the 1970 s the standard view came under heavy fire from two quarters. The radical perspective argues that women do not participate less than men, but rather participate differently. This suggests that we need to turn our attention from conventional electoral politics to a wider range of political arenas and activities, especially more ad hoc and unstructured community associations, voluntary organizations and protest groups where women are heavily committed.

\footnotetext{
*The author would like to thank colleagues who have helped with this paper. Data for this article is derived from the 1987 British Election Study cross-national survey directed by Anthony Heath, Roger Jowell, John Curtice, Julia Field and Sharon Witherspoon. The article also employed the British Social Attitude Study, 1986, provided by Social and Community Planning Research. The author is most grateful to John Curtice for assistance with providing data, and to Mary Buckley, Ivor Crewe and Joni Lovenduski for comments concerning an earlier draft.
} 
Lastly the revisionist perspective argues that women may have been less involved in mass political activity during the 1950s, but the extent of the participation gap has been exaggerated, and much of the evidence supporting the traditional view is open to criticism. In this view trends in female life-styles, notably in education, employment and the family, mean that any remaining gender differences at non-elite levels have become insignificant. We should therefore emphasize the similarities, rather than differences, in the political behaviour of women and men in the 1980 s.

The aim of this paper is critically to re-examine the traditional, radical and revisionist perspectives in the light of trends in Britain. The evidence for the analysis will be derived from the British Election Studies $(1964-87)$ and the British Social Attitudes Survey (1986). The paper will consider how far gender differences have changed in Britain in four modes of participation: voting turn-out, campaign participation, contact activity and communal participation. It will be argued that the traditional perspective is no longer adequate as the gender gap in voting, contact and campaign activity is minimal in recent years. It is more difficult to evaluate the radical perspective with the existing empirical data, which suffers from severe limitations, but the available evidence concerning communal activities throws doubt on this thesis. Therefore it will be argued that, on balance, the revisionist case seems most plausible. The paper concludes by considering some of the reasons for the changing nature of female participation and the implication of these developments.

\section{THE TRADITIONAL VIEW OF CONVENTIONAL PARTICIPATION}

According to the traditional perspective, gender is one of the standard variables, along with age, education and social class, which is a consistent predictor of political activity. During the late 1950 s a range of comparative studies noted a gender gap in voting participation, with most explanations based on sex role socialization, while some included the influence of education, employment and family responsibilities. ${ }^{1}$ In a comprehensive survey of research in the 1950 s, Lipset included gender as one of the social characteristics correlated with voting turn-out, although

${ }^{1}$ Maurice Duverger, La participation des femmes à la vie politique, UNESCO, Paris, 1955 , pp.13-74; G. Almond and S. Verba, The Civic Culture, Boston, Mass., 1965, pp.324-5; H. Tingsten, Political Behaviour, London, 1937. 
he noted sex differences were narrowing in countries such as Sweden. ${ }^{2}$ Similar conclusions were drawn by Rokkan on the basis of studies of voting turn-out in European countries ${ }^{3}$ and by others in the United States. ${ }^{4}$ Britain seemed no exception: Blondel concluded that consistent and occasional abstainers in the 1959 general election were more likely to be found among women:

It is among the less educated, the very poor, and among women that one finds the largest proportion of people who claim not to be interested in political matters. Moreover the same characteristics seem to prevail at local elections: it has been found that women and electors in large cities are more prone to abstain. $^{5}$

During the $1970 \mathrm{~s}$ this continued to be the conventional wisdom. In their comparative study, based on large-scale surveys of multi-dimensional participation in seven countries from 1966-71, Verba, Nie and Kim concluded: 'In all societies for which we have data, sex is related to political activity; men are more active than women." The study found significant sexrelated differences in participation, even when controlling for education, institutional affiliation and level of psychological involvement in politics. In reviewing the literature Milbrath suggested women's lower levels of participation was one of the most thoroughly substantiated findings in social science.

In recent years the orthodox view has been revised in terms of voting turn-out, where it is now generally acknowledged that gender differences have diminished. Many of the classic studies supporting the traditional view have been subject to an extensive critique concerning their underlying assumptions, methods and evidence. ${ }^{8}$ Nevertheless the view that women are less active in

${ }^{2}$ Seymour Martin Lipset, Political Man, London, Heinemann, 1971, pp.182-4.

${ }^{3}$ Stein Rokkan, Cítizens, Elections and Parties, Oslo, 1970

${ }^{4}$ L. Milbrath, Political Participation, Chicago, Rand McNally, 1968, p.18; R. E. Lane, Political Life, Glencoe, Illinois, Free Press, 1959, pp.204-34.

${ }^{5}$ Jean Blondel, Votes, Parties and Leaders, Harmondsworth, Pelican, 1970, pp.55- 56.

${ }^{6}$ Sidney Verba, Norman Nie and Jae Kim, Participation and Political Equality, Cambridge, Cambridge University Press, 1980, p.234.

${ }^{7}$ L. Milbrath, op. cit., p.116.

${ }^{8}$ Susan Bourque and Grossholtz, 'Politics and unnatural practice: political science looks at female participation' in Janet Siltanen and Michelle Stanworth, Women and the Public Sphere, London, Hutchinson, 1984, pp.103-21; Murray Goot and Elizabeth Reid, 'Women: if not apolitical, then conservative' in Siltanen and Stanworh, ibid.; Kathleen Jones, 'Towards a revision of politics' in Kathleen Jones and Ann Jonasdottir, The Political Interests of Gender, London, Sage, 1988, pp.20-27. 
parties and campaigns continues to represent the conventional wisdom. Lovenduski provides evidence that in the early 1980s women were under-represented as members in the major parties in most European countries. ${ }^{9}$ Even in the Nordic countries, with the most egalitarian political tradition, women form about 30-40 per cent of the party membership, and a gender difference can be discerned in attendance at political meetings and involvement in election campaigns. ${ }^{10}$

In a comparative study based on the Political Action Study, 1974-75, Dalton found gender to be a significant predictor of campaign activity, communal activity and protest politics in Britain, the United States and West Germany, though not of voting turn-out. ${ }^{11}$ A study of political apathy in America from 1960-84 concluded that there was a consistent tendency for women to be less politically engaged and less involved than men, even after controlling for educational differences. ${ }^{12}$ Therefore in the mid-1980s, after the comprehensive review of the literature Randall summarized the position: 'Overall, the evidence suggests that women's political participation, conventionally defined, is everywhere less than men's'.

\section{RADICAL THEORIES OF PARTICIPATION}

Yet there is an alternative radical perspective which developed to challenge standard assumptions about female apathy and passivity. In this model women do not participate less than men, but rather participate differently. Traditional studies can be

${ }^{9}$ See Joni Lovenduski, Women and European Politics, Brighton, Wheatsheaf, 1986, pp.135-62; M. Weber, C. C. Odorisio and G. Zincone, The Situation of Women in the Political Process in Europe, Part I, Strasbourg, Council of Europe, 1984, p.66.

10 Torild Skard and Elina Haavio-Mannila, 'Mobilisation of Women at Elections' in Elina Haavio-Mannila et al., Unfinished Democracy: Women in Nordic Politics, Oxford, Pergamon Press, 1985, pp.43-48.

"Russell Dalton, Citizen Politics in Western Democracies, New Jersey, Chatham House, 1988 , pp. $52-73$

${ }^{12}$ Stephen Earl Bennett, Apathy in America, 1960-64: Causes and Consequences of Citizen Political Indifference, Dobbs Ferry, N.Y., Transnational Publishers, 1986, pp. $72-75$

${ }^{13}$ Vicky Randall, Women and Politics, 2nd ed., London, Macmillan, 1987, p.57; see also reviews of the literature by Joni Lovenduski op. cit., pp.117-62; Weber, Odorisio and Zincone, op. cit., pp.26-52; C. Christy, Sex Differences in Political Participation: Processes of Change in Fourteen Naiions, New York, Praeger, 1987. 
criticized for neglecting the alternative political arenas within which women operate, and the type of political activities they commonly employ. It can be argued that previous research has too often relied upon a limited range of publicly accessible data concerning electoral turn-out, party activists, and membership of formal groups like trade unions. This has thereby excluded more ad hoc participation in a range of local voluntary organizations, community action groups, neighbourhood and civic groups, residents' associations and parent-teacher associations. These relatively unstructured and fragmented groups are often difficult to study systematically; yet it can be argued that these are precisely the organizations where women are particularly active. ${ }^{14}$ While these groups are not conventionally seen as political, their status should be redefined since as part of their work they can engage in activity which is designed to influence public policy, understood in broad terms.

In response, traditionalists might argue that these activities might be important, might indeed be worthy, but they should not all be considered instances of political participation. It has to be acknowledged that it is difficult to draw an appropriate distinction between social and political activity. There is, for example, a fine dividing line between industrial action and a political strike, or between fund-raising for a party and fund-raising for the Ethiopian famine. Participants in these activities may not necessarily see themselves as engaging in 'politics' since their actions are not directed, in the first instance, towards influencing the state. Nor are they using the conventional political mechanisms of parties and elections. The level of involvement may be relatively trivial and undemanding. Nor may they necessarily see themselves as formal members of an organized group or voluntary association: how does one join the women's movement?

Nevertheless in a broader conception participation in these groups can be seen as political since as part of their functions they address policy issues of public concern. These organizations can have a significant indirect impact on conventional politics. Further it can be argued that it is these sorts of groups, rather than more traditional organizations like trade unions or local planning groups, which have experienced the most substantial

\footnotetext{
${ }^{14}$ Helga Maria Hernes, The Situation of Women in the Political Process in Europe, Part III, 'The Role of Women in Voluntary Associations and Organisations', Strasbourg, Council of Europe, 1984, pp.21-31; Joni Lovenduski, op. cit., pp.126-7.
} 
growth in the 1980s. Individual membership of selected British environmental groups, for example, increased from threequarters of a million in 1971 to over three million in 1987. During the same period trade union membership fell by more than half a million. ${ }^{15}$ At the same time individual Labour Party membership fell by almost two-thirds: from 700,000 in 1971 to 266,000 in $1988 .^{16}$

The second part of the radical argument is that conventional studies have frequently neglected, not just the locus, but also the modus operandi of women's participation. It has been suggested that women are more likely to take part in politics through a heterogeneous range of ad hoc activities, involving non-violent direct action, rent strikes and boycotts, even violent protest and terrorism, rather than through electoral, parliamentary or legalistic means. ${ }^{17}$

There are deep-rooted problems using survey evidence to gauge the extent of participation in this sort of activity, which, by its nature, tends to be unstructured and transitory. During their lifetime most individuals may be relatively passive and they may not anticipate that they would take part in any form of direct action. But they may have an occasional short burst of intense political involvement triggered by particular events or issues (such recent events in Britain as the demands for the poll tax, proposed changes to the law on abortion, the introduction of student loans, or the local development of the Channel tunnel). Previous studies have therefore attempted to measure the past experience of such protest acts, and the attitudinal 'protest potential', insofar as this can be gauged satisfactorily in the absence of the catalytic events.

In their cross-national study, Barnes and Kaase found that in Britain, Austria, West Germany and the Netherlands women were slightly more likely than men to belong to the sub-category of protesters who reported they were willing to resort to direct action, while precluding conventional politics. ${ }^{18}$ Randall reports

\footnotetext{
${ }^{13}$ Social Trends, London, CSO, HMSO, op. cit., 1989, pp.176-7.

${ }^{16}$ David Butler and Gareth Butler, British Political Facts, 1900-1985, London, Macmillan, 1986; NEC Report, London, The Labour Party, 1989.

${ }^{17}$ See Randall, op. cit., pp.58-64; Lovenduski, op. cit., London, pp.126- 7; Weber, Odorisio and Zincone, op. cit., p.29.

${ }^{18} \mathrm{~S}$. Barnes and M. Kaase, et al., Political Action: Mass Participation in Five Western Democracies, Beverly Hills, Sage, 1979, p.184.
} 
that women have often played an active role in revolutionary movements, in peasant rebellions, urban guerrilla movements and nationalist uprisings. ${ }^{19}$ Studies of terrorism in West Germany have found a disproportionate number of women in these groups. ${ }^{20}$ Weber found that younger and more educated women were most inclined towards political protest, even violent protest in Italy, the Federal Republic of Germany and the Netherlands. ${ }^{21}$ Nevertheless the position is not -clear-cut. In contradiction Dalton found protest to be more common among men in the United States, Britain and West Germany, ${ }^{22}$ and Marsh drew similar conclusions based on a British survey in the mid-1970s. ${ }^{23}$

If we accept the radical argument this implies that political participation is more widespread than traditional accounts would suggest. In the classic analogy, the mass of citizens were seen as spectators watching a few football players compete in the first division teams. Party politics may continue to be a minority sport. But it can be argued that the image is as outdated as it is inherently sexist. In the radical perspective today most citizens have come down from the terraces to be active, now and then, in a diverse range of local sports - from jogging and squash to aerobics. In this view political participation has to be seen as multi-dimensional, with diverse locations and varied activities outside the traditional electoral, partisan and lobbying arenas. The radical critique suggests that analysis of political participation has to take into account horizontal segregation by gender, with the possibility that women and men may be members of different organizations and may participate in different ways, as well as vertical segregation within the same organization. It is difficult to test these propositions with the existing survey evidence, which has certain inherent assumptions about the nature of political activity built into its epistemological and methodological framework. It can be argued that traditional studies of participation have assumed male norms of citizenship, described by such activities as voting, campaigning or lobbying, then sought to explain why women have failed to act like men, rather than exploring female-oriented modes of political

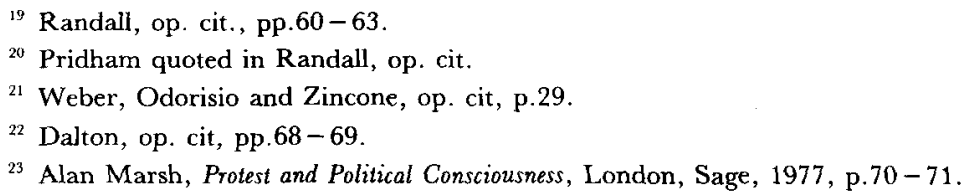


behaviour. ${ }^{24}$ Nevertheless we can use the available material to go beyond the electoral arena to see whether women in Britain are more likely than men to take part in, or express approval of, protest activity and communal forms of political participation.

\section{THE REVISIONIST ACCOUNT OF PARTICIPATION}

Yet there is the third perspective: that, apart from elected office, gender differences in political activity have diminished to an insignificant level over the years. As Carroll summarized the position in the United States in 1979: '...the picture which emerges is not one of marginality but of women holding political attitudes and engaging in political behaviours very similar to those of men...On almost all measures of voting, participation, efficacy, activism, ideology, and performance, sex differences, if present at all, are small. ${ }^{25}$ Given changing female life-styles in terms of education, employment and organizational affiliations we might expect the participation gap to decrease over time.

In the United States the gender difference in turn-out declined from the 1950 s to the 1980 s, according to the series of American National Election Studies. ${ }^{26}$ Official figures from the US Census Office confirm this trend, and suggest that the position has now reversed, with a slightly higher proportion of women than men reporting that they registered, and voted, in the 1984, 1986 and 1988 elections. ${ }^{27}$ During the 1980 s there have been similar developments in the Nordic countries with heavier electoral turnout by women in Sweden, Finland and Iceland. ${ }^{28}$ The literature, therefore, suggests the need to look at trends in Britain from 1964 to 1987 to examine whether women continue to be less active in conventional forms of participation or, alternatively, whether gender differences in voting participation, campaign activity and communal activity have decreased, or even reversed, over time.

${ }^{24}$ Jones, op. cit., pp. $22-3$.

${ }^{25}$ Bernice Carroll, 'Review Essay: Political Science, Part I: American Politics and Voting behaviour', Signs, Vol. V, No. 2, 1979, p.292; see also Karen Beckwith, American Women and Political Participation, Westport, Connecticut, Greenwood Press, 1986.

${ }^{26}$ Warren E. Miller and Santa A. Traugott, American National Election Studies Data Sourcebook, 1952-1986, Cambridge ${ }_{\mathfrak{\imath}}$ Mass., Harvard University Press, 1989.

${ }^{27}$ Harold W. Stanley and Richard G. Niemi, Vital Statistics on American Politics, Washington, DC, CQ Press, 1990.

${ }^{28}$ Skard and Haavio-Mannila, op. cit, p.40. 
To examine trends in Britain we will analyse data from the series of British General Election Studies, from 1964 to 1987. While including only a limited range of questions on participation, and lacking continuity concerning certain items, these surveys have the advantage of providing some indication of trends over the last twenty-five years. For more detailed information on communal and contact activists, data will be drawn from the British Social Attitudes Survey, 1986. Following the work of Verba, Nie and $\mathrm{Kim}^{29}$ the diverse range of political activities will be classified into four modes or types of participation: voting, campaign participants, communal activists and contact specialists.

Considerable attention has focused on voting turn-out, given the widespread availability of electoral statistics and the symbolic importance of the franchise, although the relationship between voting and other forms of political activity can be questioned. In the past voting was often seen as the first rung on a unidimensional ladder, but, as Verba, Nie and Kim have argued, it seems more appropriate to regard it as an atypical form of participation, since it involves minimal initiative and effort. Voting specialists will be defined as those who limit their activity to voting.

Campaign activity can be seen to represent an extension of electoral participation which is more demanding than voting, and which often involves the need to cooperate with others. Campaign activists will be defined as those who vote and perform at least one activity within the election, such as canvassing or working for a candidate, displaying a party poster, hearing a candidate at a meeting, following the campaign on the media, or being a party member.

Contact specialists are those who participate in particular issues by contacting their MP or other influential person, government departments or the media. This sort of activity requires a high level of individual initiative and information, but little cooperation with others in a group. Lastly there are communal activists, defined as those who go on a demonstration or protest march, sign a petition, raise an issue within an organization or form a group with others who share their concerns. While some of these activities can be seen as conventional today, in other respects communal activists shade into the area of protest politics.

${ }^{29}$ Verba, Nie and Kim, op. cit. 


\section{GENDER DIFFERENCES IN VOTER TURN-OUT?}

First, in the light of this discussion, we will turn to the question of how far gender differences in voting participation have diminished over time. It is commonly assumed that for many years after the franchise was granted women continued to vote at lower rates, despite the parties' initial attempts to mobilize this new pool of voters, although evidence for this is difficult to substantiate. There are three sources of evidence to measure voter abstention: the official electoral register, aggregate results and opinion polls. In Britain the Registrar General recorded the number of men and women registered as electors at each general election from 1918 until 1935, when the practice ceased. ${ }^{30}$ In Britain, unlike some countries, there is no public official record of voter participation by sex. ${ }^{31}$ The first systematic opinion polls in Britain started in 1937, with the establishment of the British Institute of Public Opinion (Gallup Polls). As a result the only reliable evidence about the impact of the 1918 and 1929 extensions to the franchise has to rest on aggregate levels of turn-out.

The franchise was extended in two stages: the Representation of the People Act 1918 allowed women over 30 to vote, as a result of which women formed about 43 per cent of the registered electorate. In 1928 the Equal Franchise Act lowered the voting age of women to 21, the same as for men. By 1929 women formed the majority of the electorate ( 53 per cent), due to their greater longevity, accentuated by war. What effect did the 1918 and 1929 Acts have on aggregate turn-out? In the 1918 general election voting participation fell sharply from 82 to 57 per cent, compared with the previous contest. The effect could be attributed in part to the enfranchisement of women but equally this could be due to the massive demobilization of soldiers returning from the First World War, the disruption of civilian life, changes in the party system with the collapse of the Liberal vote and the rise of Labour, and the enfranchisement of some categories of workingclass men who had not previously had the vote. Turn-out recovered in subsequent elections, with the general pattern over the years of trendless fluctuations around the 75 per cent mark (see Diagram 1). The 1929 Act had no discernible effect on changes in turn-out in the 1929 and 1931 elections.

\footnotetext{
${ }^{30}$ F.W.S. Craig, British Electoral Facts, 1832-1987, Dartmouth, Parliamentary Research Services, 1989, p.89.

3. For France and Germany, however, see Maurice Duverger, La participation des femmes à la vie politique, Paris, UNESCO, 1955, pp.14-20.
} 


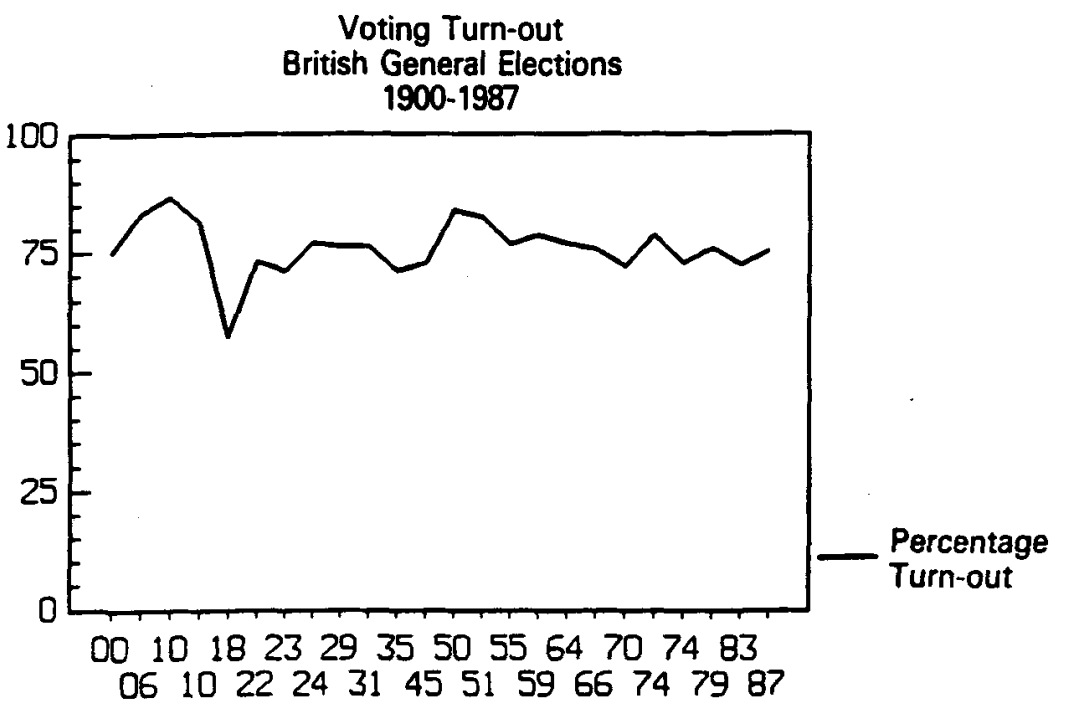

By the mid- to late 1960 s the first systematic survey evidence in Britain found a modest gender gap in voting. Baxter and Lansing note that in the 1964 British general election reported voting turnout was 90 per cent for women and 92 per cent for men. In the 1970 election reported turn-out was 83 per cent for women and 87 per cent for men. ${ }^{32}$ Yet Crewe, Fox and Alt, in the most thorough investigation of non-voting in Britain, used panel data from four general elections from 1966 to October 1974 to examine consistent abstainers. The study concluded that gender failed to have any significant impact on the propensity to vote regularly, especially once the greater longevity of women was taken into account. Voters and non-voters were found to share very similar sociological characteristics in most respects, with the notable exceptions of age, marital status and geographic mobility. ${ }^{33}$

${ }^{32}$ Sandra Baxter and Marjorie Lansing, Women and Politics: The Visible Majority, Ann Arbor, University of Michigan Press, 1983, p.150.

${ }^{33}$ Ivor Crewe, Anthony Fox and James Alt, 'Non-voting in British General Elections 1966-October 1974' in Colin Crouch (ed.), British Political Sociology Yearbook, Vol. 3, London, Croom Helm, 1977, pp.52-4. 
Table 1

Reported Voting Participation by Gender, 1964- 87 (Britain)

\begin{tabular}{lccc}
\hline & Male & Female & Difference \\
\hline 1964 & 92 & 90 & -2 \\
1966 & 85 & 83 & -2 \\
1970 & 87 & 83 & -4 \\
$1974(0)$ & 85 & 85 & 0 \\
1979 & 84 & 85 & +1 \\
1983 & 82 & 84 & +2 \\
1987 & 85 & 87 & +2 \\
\hline
\end{tabular}

Source: British Election Studies, $1964-87$

The evidence of trends available in the series of British Election Studies from 1964 to 1987 confirms that in the past there was a minor gender difference in reported voting turn-out. Without controlling for the effects of age or education it is apparent that slightly fewer $(3-4$ per cent) women than men participated in general elections during the mid-1960s. Nevertheless this gap disappeared by the early 1970s (see Table 1), and may have reversed among younger women in the 1980s.

Although these surveys provide an indication of trends over time this evidence remains unreliable, since there is a well-known tendency to exaggerate turn-out in surveys. ${ }^{34} \mathrm{We}$ can check these findings with data on actual turn-out, derived by Kevin Swaddle $^{35}$ from official records. These data confirm the reverse gender gap: in the 1987 general election, among the younger and middle-aged, a higher proportion of women than men turned out to vote (see Table 2). We can extrapolate from this pattern, and population trends based on greater female longevity, to estimate that in the 1987 general election about 1.6 million more women than men voted. This confirms the conclusions of Moyser and Parry, based on their survey in 1984-85, which found that slightly more women than men reported voting in local, general

${ }^{34}$ See Kevin Swaddle and Anthony Heath, 'Official and reported turnout in the British General Election of 1987', British Journal of Political Science, 1989.

${ }^{35}$ The information on turn-out in the 1987 general election was derived independently of the 1987 British Election Study from records held in the Lord Chancellor's office by Kevin Swaddle. Given the systematic bias towards over-reporting, voting participation was checked against actual, rather than reported turn-out. 
Table 2

Turn-out in the 1987 British General Election by Gender and Age

\begin{tabular}{lccc}
\hline Age Group & Male & Female & Difference \\
\hline Younger $(18-29)$ & 65 & 70 & +5 \\
Middle $(30-59)$ & 81 & 83 & +2 \\
Older $(60+)$ & 85 & 79 & -6 \\
All & 82 & 83 & +1 \\
\hline
\end{tabular}

Source: Swaddle, British Election Study, 1987 (see notes).

and European elections, especially once the analysis controlled for differences in personal and resource factors. ${ }^{36}$

\section{GENDER DIFFERENGES IN CAMPAIGN ACTIVITY?}

Turning to campaign and party activity it has commonly been found that gender differences increase with the more demanding types of participation. Crewe, Fox and Alt, based on the British Election panel survey from 1964-70, support the traditional view. The study found that gender was significant as a predictor of all types of conventional participation in Britain other than voting, since men were found to represent 48 per cent of voters, but 65 per cent of party members, 62 per cent of the members of other political groups, and 56 per cent of those active in other political groups. ${ }^{37}$ These figures received further confirmation by estimates of individual party membership in Britain. No recent official figures are available from the parties but in the 1970s Jill Hills estimated that women constituted 40 per cent of Labour Party members and 51 per cent of Conservative Party members. ${ }^{38}$

Yet certain more recent studies have questioned this finding. Welch examined a range of activities in the 1963 and 1974 British Election Studies, including voting, party membership, party work and interest groups activity, and reported insignificant

${ }^{36}$ George Moyser and Geraint Parry, 'A Map of Politícal Participation in Britain', paper presented at the Conference of Political Participation, Manchester, 1990, p.22,; George Moyser, Geraint Parry and Neil Day, 'Political Participation in Britain: National and Local Patterns', paper presented at the Annual Meeting of the American Political Science Association, Washington DC, 28-31 August 1986, p.28.

${ }^{37}$ Crewe, Fox and Alt, op. cit., pp.52-4.

38 Jill Hills, 'Britain', in Joni Lovenduski and Jill Hills, The Politics of the Second Electorate, London, Routledge \& Kegan Paul, 1981. 
differences between women and men. ${ }^{39}$ In their more recent study Moyser, Parry and Day concluded that by the mid-1980s there were no simple generalizations about women's participation. After sub-dividing their sample into seven categories of activist the authors concluded:

Overall, our impression is that...gender does not have a very strong relationship with type of participant...it is clear that the pattern is not simply one of men being more active than women, or vice versa. Our rather complex mapping of the population shows a more complex relationship. Thus, men are slightly overrepresented, and women under-represented, amongst our small band of complete activists. However the same pattern, albeit even weaker, applies to the much larger group of the politically inert! Equally, amongst the various specialist categories, men loom somewhat larger in contacting and protesting, but women have the upper hand very slightly amongst voters, groups and, more strikingly, party campaign workers. ${ }^{40}$

Evidence in the series of British General Election Studies confirms that in 1964 women were slightly less likely to take part in party and campaign activity but suggests that by the early 1980s these differences had disappeared (see Table 3). In the 1987 election there were no significant differences between male and female participation in canvassing, party membership or other forms of campaign activity with the sole exception of newspaper readership. The latter can be seen to reflect long-standing differences in leisure patterns, rather than political interest, knowledge or involvement in the campaign. The evidence also confirms that beyond following the election in the media most people took a minimal part in political life, and it could be argued that during the intensive period of the formal campaign it would be difficult for anyone in Britain to avoid hearing something about the election on the radio or television.

\section{GENDER DIFFERENCES IN CONTACT SPECIALISTS AND COM- MUNAL ACTIVISTS}

In terms of activities outside of the conventional electoral arena contact specialists can be seen as a distinctive group who are prepared to invest time and effort in writing to parliament, the press or Whitehall about particular issues of concern. The 1986 British Social Attitude Survey attempted to measure actual, and

39 Susan Welch, 'Sex Differences in Political Activity in Britain,' Women and Politics, Vol. 1: 2, Summer 1980. pp.29-46.

*0 Moyser, Parry and Day, op. cit., p.28. 
Table 3

Campaign Activity by Gender, 1964-87

\begin{tabular}{|c|c|c|c|c|}
\hline & & $\begin{array}{c}\text { Male } \\
\text { per cent Yes }\end{array}$ & $\begin{array}{c}\text { Female } \\
\text { per cent Yes }\end{array}$ & Difference \\
\hline $\begin{array}{l}\text { Listened to } \mathrm{TV} / \text { radio } \\
\text { about campaign }\end{array}$ & $\begin{array}{l}1964 \\
1966 \\
1983 \\
1987\end{array}$ & $\begin{array}{l}85 \\
75 \\
81 \\
81\end{array}$ & $\begin{array}{l}79 \\
70 \\
80 \\
81\end{array}$ & $\begin{array}{r}-6 \\
-5 \\
-1 \\
0\end{array}$ \\
\hline $\begin{array}{l}\text { Read newspaper } \\
\text { about campaign }\end{array}$ & $\begin{array}{l}1964 \\
1966 \\
1983 \\
1987\end{array}$ & $\begin{array}{l}73 \\
66 \\
77 \\
75\end{array}$ & $\begin{array}{l}57 \\
50 \\
64 \\
61\end{array}$ & $\begin{array}{l}-16 \\
-16 \\
-14 \\
-14\end{array}$ \\
\hline $\begin{array}{l}\text { Displayed party poster } \\
\text { during campaign }\end{array}$ & $\begin{array}{l}1979 \\
1983 \\
1987\end{array}$ & $\begin{array}{r}8 \\
11 \\
12\end{array}$ & $\begin{array}{r}8 \\
11 \\
11\end{array}$ & $\begin{array}{l}0 \\
0 \\
0\end{array}$ \\
\hline $\begin{array}{l}\text { Individual member of } \\
\text { any party }\end{array}$ & $\begin{array}{l}1964 \\
1974(0) \\
1983 \\
1987\end{array}$ & $\begin{array}{r}11 \\
7 \\
9 \\
6\end{array}$ & $\begin{array}{l}9 \\
6 \\
6 \\
6\end{array}$ & $\begin{array}{r}-2 \\
-1 \\
-3 \\
0\end{array}$ \\
\hline $\begin{array}{l}\text { Attended political } \\
\text { meeting during } \\
\text { campaign }\end{array}$ & $\begin{array}{l}1964 \\
1979 \\
1983 \\
1987\end{array}$ & $\begin{array}{r}11 \\
5 \\
5 \\
3\end{array}$ & $\begin{array}{l}5 \\
2 \\
3 \\
2\end{array}$ & $\begin{array}{l}-6 \\
-3 \\
-2 \\
-1\end{array}$ \\
\hline $\begin{array}{l}\text { Went canvassing/ } \\
\text { worked for } \\
\text { candidate }\end{array}$ & $\begin{array}{l}1979 \\
1983 \\
1987\end{array}$ & $\begin{array}{l}2 \\
3 \\
3\end{array}$ & $\begin{array}{l}1 \\
3 \\
2\end{array}$ & $\begin{array}{r}-1 \\
0 \\
-1\end{array}$ \\
\hline
\end{tabular}

Source: British General Election Studies, 1964-87

potential, involvement in this mode of activity. The results show there were considerable discrepancies between the two: only one in ten had ever contacted their representative in parliament but more than half said that they would write to their MP about a particular issue (see Table 4). Overall the results suggest that contacting was a minority activity, and there were no consistent gender differences in this mode of participation, except in terms of efficacy. Women were far more likely than men to see these actions as effective in influencing the government.

The last mode is communal and protest activity, which raises difficult issues of measurement. The British Social Attitudes Survey attempted to gauge the extent of actual and potential 
Table 4

Contact Activity by Gender

\begin{tabular}{lrrrr}
\hline & Men & Women & Diff. & TauB \\
\hline 'EVER DONE...' & & & & \\
Contacted MP & 12 & 10 & -2 & .04 \\
Spoken to influential person & 4 & 2 & -2 & .06 \\
Contacted government dept & 3 & 2 & -1 & .02 \\
Contacted radio, TV, newspaper & 3 & 3 & 0 & .01 \\
\hline
\end{tabular}

N. $1,548 * *=p>.01 \quad *=p>.05$

Source: British Social Attitude Study, 1986

support for this sort of activity by asking respondents whether they had ever, or would ever, sign a petition, raise an issue within a group, form a group of like-minded activists, or participate in a protest or demonstration. Generally the results support the revisionist rather than radical perspective: responses to these questions indicate no consistent gender differences, with the exception of marginally higher fermale efficacy (see Table 5). The same pattern was evident when people were questioned in the survey about their response to issues of environmental concern. People were asked how they would respond to issues such as a local housing development which encroached on the countryside, a protected area which was being ploughed up for farmland and the danger to the forests from acid rain. Again there were no significant gender differences when people were presented with a range of possible activities, from contacting their local councillor, to joining a conservation group, giving money or volunteering for a campaign, or remaining inactive.

To examine the protest potential in more detail respondents in the 1986 British Attitudes Survey were asked whether they would allow a range of protest activities against the government, from public meetings to demonstrations, industrial militancy and occupations of government offices. These questions are similar, although not identical, to those used by Alan Marsh to assess protest potential in the mid-1970s. ${ }^{41}$ In addition in the 1979 British Election Study people were also asked about their willingness to take different forms of direct action, including rent strikes, occupations and illegal marches (see Table 6). As previous studies have indicated, the results suggest a high level of tolerance

4 Marsh, op. cit. 
Table 5

Communal Activity by Gender

\begin{tabular}{lrrrl}
\hline & Men & Women & Diff. & TauB \\
\hline 'EVER DONE... & & & & \\
Signed petition & 33 & 35 & +2 & .03 \\
Raise issue in group & 5 & 4 & -1 & .02 \\
Gone on protest/demonstration & 6 & 5 & -1 & .03 \\
Formed group of like-minded & 2 & 1 & -1 & .02 \\
\hline
\end{tabular}

Note: see survey items in previous table.

Source: British Social Attitude Study, 1986

Table 6

Protest Potential by Gender, 1979

\begin{tabular}{lcccc}
\hline $\begin{array}{l}\text { 'Very or quite likely } \\
\text { respondent would...' }\end{array}$ & $\begin{array}{c}\text { Male } \\
\text { percentage }\end{array}$ & $\begin{array}{c}\text { Female } \\
\text { percentage }\end{array}$ & Diff & TauB \\
\hline $\begin{array}{l}\text { Help collect signatures for } \\
\text { petition }\end{array}$ & 42 & 46 & +4 & .04 \\
Go on legal protest march & 21 & 19 & -2 & .04 \\
Refuse to pay rates/tax/rent & 22 & 21 & -1 & .00 \\
Occupy building & 7 & 8 & +1 & .01 \\
Go on banned protest march & 5 & 3 & -1 & .07 \\
Disrupt a meeting & 3 & 5 & +2 & .07 \\
Try to block traffic & 3 & 3 & 0 & .04 \\
\hline
\end{tabular}

Note: $Q$...If there is anything you felt strongly about, how likely is it that you would do some of the following things to get the authorities to change their mind?

Source: British General Election Study, 1979

for the more conventional items, but little support was expressed for the radical or violent actions. In terms of gender these were minimal differences, although women were marginally less willing to approve of these forms of protest action. This evidence is admittedly limited, and fails to take account of a diverse range of activities in voluntary associations and informal ad hoc groups, but nevertheless the results seem to lend little support to the radical case. 
Table 7

Multivariate Analysis of Political Participation

\begin{tabular}{|c|c|c|}
\hline \multicolumn{2}{|l|}{ Independent Variables } & Mode of Participation \\
\hline $\begin{array}{l}\text { Gender } \\
\text { Age } \\
\text { Education } \\
\text { Social Class } \\
\text { Strength of Party Ident. } \\
\text { Political Interest }\end{array}$ & $\begin{array}{l}.01 \\
.05^{*} \\
.02 \\
.01 \\
.05^{*} \\
.27^{*}\end{array}$ & VOTING SPECIALISTS $\mathrm{R}=.28$ \\
\hline $\begin{array}{l}\text { Gender } \\
\text { Age } \\
\text { Education } \\
\text { Social Class } \\
\text { Party Ident. } \\
\text { Political Interest }\end{array}$ & $\begin{array}{l}.01 \\
.05^{*} \\
.05^{*} \\
.03 \\
.21^{*} \\
.09^{*}\end{array}$ & CAMPAIGN ACTIVISTS $\mathrm{R}=.26$ \\
\hline $\begin{array}{l}\text { Gender } \\
\text { Age } \\
\text { Education } \\
\text { Social Class } \\
\text { Party Ident. } \\
\text { Political Interest }\end{array}$ & $\begin{array}{l}.01 \\
.02 \\
.08^{*} \\
.07^{*} \\
.05^{* *} \\
.25^{* *}\end{array}$ & CONTACT SPECIALISTS $\mathrm{R}=.30$ \\
\hline $\begin{array}{l}\text { Gender } \\
\text { Age } \\
\text { Education } \\
\text { Social Class } \\
\text { Party Ident. } \\
\text { Political Interest }\end{array}$ & $\begin{array}{l}.05 \\
.06 \\
.04 \\
.02 \\
.04 \\
.28^{* *}\end{array}$ & COMMUNAL ACTIVISTS $\mathrm{R}=.29$ \\
\hline \multicolumn{3}{|c|}{$\begin{array}{l}\text { Note: The figures represent standardized regression coefficients (betas) } \\
\text { measuring the relative impact of each variable on the mode of activity. The } \\
\text { codings are education (graduate/non-graduate), social class (manual/non- } \\
\text { manual occupation), housing tenure (council tenants/non-council), party } \\
\text { identification (strong/not strong). } \\
\text { Source: British General Election Survey, 1987; British Social Attitudes Survey, } \\
\text { 1986. }\end{array}$} \\
\hline
\end{tabular}
1986.

\section{CONCLUSIONS AND DISGUSSION}

So far in this paper we have only been concerned with simple bivariate relationships describing the extent of male-female participation under these different modes, but in conclusion we need to consider the relative impact of gender controlling for the other factors which are commonly found to be associated with 
political activity. Previous studies have usually stressed the role of education, as political participation requires information to stay abreast of developments and to be knowledgeable about the choices on offer. Age and housing tenure need to be taken into account since Crewe, Fox and Alt stressed that these were among the most significant indicators of voting turn-out in Britain. ${ }^{42}$ In addition we need to control for the independent influence of social class, defined along the manual/non-manual occupational divide, since middle-class occupations might be expected to provide resources (time and money) which facilitate political activity. Lastly among political attitudes we need to take account of strength of partisan identification and political interest, which previous studies have found to be a more important influence on voting turn-out than social characteristics.

If we control for the relative importance of these factors, using least squared multiple regression analysis, the results confirm the evidence which has been presented concerning the insignificance of gender as a predictor of participation in any of these modes of activity (see Table 7). While age and education influence political activity, the most important factors to emerge from this analysis are attitudinal rather than socio-economic or demographic. This lends further confirmation to what others have found in previous studies: what distinguishes participants from non-participants are primarily motivational factors - political interest, efficacy and partisan loyalties.

We can therefore conclude that the traditional view, that women are more passive and uninvolved in conventional political life may have had some validity in the past, although much of the evidence in previous studies is open to criticism, and there has often been a tendency to exaggerate the extent and significance of the gender gap. Nevertheless the conventional view is no longer valid today as women and men are remarkably similar in their mass behaviour and attitudes across all modes of participation. If we can accept that this is the case then one ghost in political science will finally be laid to rest, although it reinforces the significance of another question: if gender is so unimportant in mass political activity then why are there so few women at the apex of power?

\footnotetext{
${ }^{42}$ Crewe, Fox and Alt, op cit.

${ }_{43}$ Crewe, Fox and Alt, op. cit., pp.63-89.
} 